be even lower. This would have increased the deception rates in the other two groups.

$\mathrm{COHb}$ concentrations may be raised by factors other than smoking. These include leaking motor-car exhausts, pollution in streets and tunnels, industrial and domestic pollution, and, rarely, haemolytic anaemias. Non-smoking police on point-duty in Fleet Street were found to have only slightly raised values (mean $1.9 \%$ ). ${ }^{8}$ Only heavy exposure to the smoke of others causes raised $\mathrm{COHb}$ concentrations in non-smokers. ${ }^{9}$ We have no reason to believe that any of these factors were present in our study. If any had been, however, all groups should have been affected to some extent.

A sensitive nose and a sceptical attitude towards patients who assert that they have stopped smoking will detect many who have not. No great clinical acumen is needed to detect those with stained fingers or smoky breath. But for others more discerning methods may be required. For this purpose $\mathrm{COHb}$ estimation is a valuable objective test. The half life of $\mathrm{COHb}$ in resting subjects is about four hours, and it may take 24 hours for normal values to be reached after stopping smoking. Few heavy smokers can stop this long even if forewarned. When raised $\mathrm{COHb}$ concentrations are found in those claiming they do not smoke other sources of exposure should be sought, though in our experience these are rare.

We found that a high proportion of subjects who claimed to have stopped were still smoking. Thus $\mathrm{COHb}$ estimation acted as a useful lie-detector. Patients confronted with a raised $\mathrm{COHb}$ concentration often remember the cigarettes smoked that they had "forgotten." The subjects in groups A and B were not aware that their veracity was being tested when the blood samples were taken.

If our findings are typical then the results of trials depending on patients' statements that they had stopped smoking need to be reassessed. For instance, among those attending the stopsmoking clinic (group B) 59\% claimed to have stopped smoking after one month, but in only $32 \%$ was this confirmed by $\mathrm{COHb}$ estimation.

Studies showing improved prognosis in ex-smokers may have underestimated the true benefit of stopping smoking by including some people who continued to smoke. Likewise results of anti-smoking clinics and other cessation trials may have been worse than actually reported. Probably, of course, many subjects whose stated cessation was not confirmed had considerably reduced their consumption. This is supported by the results in our group $\mathrm{B}$, in which the mean $\mathrm{COHb}$ concentration in the 33 "unconfirmed" subjects fell from $7 \cdot 6 \%$ to $2.9 \%$. This may be compared with the "confirmed" subjects, whose mean concentration fell from $6.2 \%$ to $1 \cdot 3 \%$. Stopping smoking must remain the criterion of success, since heavy cigarette smokers who reduce but do not stop smoking often return to their previous level of consumption.

Although we used $1.7 \%$ as the critical value for $\mathrm{COHb}$ क concentration, other laboratories will probably use different $\overrightarrow{0}$ values. Methods and instruments for measuring $\mathrm{COHb}$ are not standardised, and each centre should produce its own normal $\vec{\omega}$ range.

We thank members of staff for providing blood samples. We are also grateful to $\mathrm{Dr} M \mathrm{~W}$ McNicol and $\mathrm{Dr} J$ A McM Turner for $\sigma$ advice; Mrs L Bywater for help in collating the data; and A B Leo and $\vec{A}$ Company, Helsingborg, Sweden, for financial support.

\section{References}

1 Jones, R D, Commins, B T, and Cernik, A A, Lancet, 1972, 2, 302.

2 Sillett, R W, Turner, J A McM, and Ball, K P, in Proceedings of Third World Conference on Smoking and Health, ed E L Wynder, D Hoffman, and G B Gori, vol 1, p 343. Washington, DC, Government Printing Office, 1975.

3 Russell, M A H, et al, British Medical fournal, 1976, 2, 391.

4 Turner, J A McM, British Medical fournal, 1976, 2, 755.

5 Russell, M A H, British Medical fournal, 1976, 2, 755.

6 Malcolm, R E, et al. In preparation.

${ }^{7}$ Sillett, $R$ W. In preparation.

${ }^{8}$ Lawther, P J, and Commins, B T, Annals of the New York Academy of Sciences, 1970, 174, 135.

${ }^{9}$ Russell, M A H, Cole, P V, and Brown, E, Lancet, 1973, 1, 576.

\title{
Amniotic fluid cell morphology in early antenatal prediction of abortion and low birth weight
}

\author{
CHRISTINE GOSDEN， D J H BROCK
}

British Medical fournal, 1978, 2, 1186-1189

\section{Summary and conclusions}

The morphology of rapidly adherent (RA) amniotic fluid cells was examined in 201 pregnant women referred for amniocentesis because of two sequential high serum $\alpha$-fetoprotein (AFP) concentrations. Out of 43 amniotic fluid samples containing increased amounts of AFP, 42 had neural or peritoneal cells predominating among the RA cells, the outcome being an infant with a neural-tube defect or exomphalos. In the other case with a raised amniotic fluid AFP concentration but only anterior placental cells the infant was normal.

Western General Hospital, Edinburgh EH4 2XU

CHRISTINE GOSDEN, PHD, scientist, MRC Clinical and Population Cytogenetics Unit

D J H BROCK, PHD, reader in human genetics
In 25 amniotic fluid samples containing normal $D$ amounts of AFP distinctive new patterns of RA cells were observed, termed fetal distress cells. These pregnan- $N$ cies resulted in five spontaneous abortions and 20 infants $N$ with birth weights under 2500 g. Fetal distress cells were $\underset{\sigma}{\sigma}$ not detected in any of the remaining 133 samples. One pregnancy was terminated because of a chromosomal $\stackrel{\varrho}{\circ}$ abnormality, and there were seven twin pairs not recog- $\$$ nised on ultrasonography before amniocentesis. The remaining 125 pregnancies went to term, resulting in infants with birth weights exceeding $2500 \mathrm{~g}$.

The results suggest that RA-cell morphology will prove to be of value in the early antenatal prediction of spontaneous abortion and low birth weight.

\section{Introduction}

Maternal serum $\alpha$-fetoprotein (AFP) screening has proved valuable in the early antenatal diagnosis of fetal neural-tube defects. ${ }^{1-3}$ A raised serum AFP concentration, however, may 
also indicate other types of fetal malformation, such as exomphalos, ${ }^{4}$ congenital nephrosis, ${ }^{5}$ and Meckel's syndrome, ${ }^{6}$ as well as spontaneous ${ }^{7}$ and missed abortions. ${ }^{8}$ Furthermore, three independent studies have shown significant associations between high maternal serum AFP concentrations in the second trimester and the delivery of infants of low birth weight. ${ }^{9-11}$

Interpretation of raised maternal serum AFP values depends on ultrasonography and amniocentesis. We have shown that a combination of amniotic fluid AFP assay and examination of the morphology of rapidly adherent (RA) amniotic fluid cells allows a differential diagnosis of neural-tube defect, exomphalos, and missed abortion to be made. ${ }^{12-17}$ We now present evidence that RA-cell morphology is also valuable in the early antenatal prediction of spontaneous abortion and low birth weight.

\section{Materials and methods}

For three years all pregnant women attending a group of local hospitals have been offered serum AFP screening for neural-tube defects. ${ }^{3}$ Women with two sequential AFP values above the 95 th percentile of the normal range were referred for

further clinical investigation and possible ultrasonic scanning. A total of 202 patients who showed no clinical signs of threatened abortion whose gestational age was confirmed by ultrasonic estimation of biparietal diameter, and who appeared not to be carrying twins were referred for amniocentesis. In one patient with oligohydramnios three attempts at amniocentesis at 19 weeks failed to produce fluid. At 25 weeks she aborted a fetus with Potter's syndrome. From the remaining 201 women samples of amniotic fluid, adequate for both karyotype analysis and the studies reported here, were obtained.

\section{AFP ESTIMATION}

Serum AFP concentrations were measured by single-step, solidphase radioimmunoassay, ${ }^{18}$ and amniotic fluid AFP concentrations by Rocket immunoelectrophoresis. ${ }^{19}$

\section{CELL CULTURE FOR RA AMNIOTIC FLUID CELLS}

Total, viable, and red blood cell counts were analysed as described.12141617 The number and types of cells adherent to each coverslip were analysed and the cellular adherence expressed as a percentage of the number of viable cells originally suspended over the coverslip.

\section{CELL TYPES}

Neural cells-There are four major types of neural cells: (a) long cells $(b)$ cells with multiple fine pseudopodial processes, $(c)$ large cells with vacuoles and inclusion bodies, and $(d)$ giant multinucleated cells with inclusions and vacuoles.12 1417 They occur in amniotic fluid only when there is a lesion in the central nervous system.

Peritoneal cells-There is only one major peritoneal cell type, which has a fine lace-like cytoplasm. The nucleus is large and may be central or at one end of the cell. Binucleated cells are common, and larger cells containing several nuclei are occasionally seen; these also have the characteristic lace-like cytoplasm. Peritoneal cells occur in amniotic fluid when the fetus has exomphalos or gastroschisis. 121617

Anterior placental cells are small with dense cytoplasm and a nucleus placed so eccentrically that it often appears as a cap at one end. There may be more than one nucleus, but even these multinucleates are small and have dense, uniformly staining cytoplasm with no vacuoles. Anterior placental cells may be present in combination with other RA cell types but appear only when the placenta is traversed during amniocentesis. They may aid interpretation when there is a marginally increased amniotic fluid AFP concentration with blood-stained fluid. 121317

Epithelioid cells are the only major cell type in normal amniotic fluid that adheres to glass in 20 hours. They are usually square or hexagonal and are desquamated fetal skin or epithelial cells. They are very thin, and folds are often seen. The cytoplasm stains uniformly, and the nucleus is small and central (see figure (a)).

Fibroblasts rarely adhere to glass in 20 hours but occasionally occur in amniotic fluid when the fetus is normal. The characteristic ruffling membrane can be seen.

Fetal distress cells type I are large, round cells with a quite prominent cell membrane. The nucleus is invariably small, intensely stained, and central. The cytoplasm appears diffuse and pale-staining with no prominent features (see figure $(b, c)$ ).

Fetal distress cells type $I I$ are small (especially when compared with neural cells). Their shape may vary considerably, although many are triangular or square. The nucleus may be central or near to the centre and usually has prominent nucleoli. The most characteristic feature is the large, irregular vacuoles in the cytoplasm, usually placed immediately adjacent to the nuclear membrane (see figure $(d-f)$ ). 


\section{CHROMOSOME STUDIES}

Chromosome studies were performed on cultured amniotic fluid cells obtained at amniocentesis, on cardiac blood taken from abortuses at necropsy, on cultured fetal tissue from necropsy material, and on cord blood samples from the live-born infants. The studies were carried out as described. ${ }^{20} 21$

\section{Results}

Table I gives the RA-cell morphology in the 201 samples of amniotic fluid. The cases are divided into three groups.

\section{RAISED AMNIOTIC FLUID AFP VALUE AND ABNORMAL RA CELIS}

Of the 43 pregnancies in this category, 40 were associated with fetal neural-tube defects. In one case in which the fetus had anencephaly and exomphalos both neural and peritoneal cells were apparent. In two cases of exomphalos there were extremely high AFP values (over 10 standard deviations above the mean) with no blood contamination. The cellular adherence values were $9 \%$ and $11 \%$. Only peritoneal cells were present. In several cases placental cells were adherent to glass after an anterior placenta or partially anterior placenta had been traversed during amniocentesis. In one case the penetration of an anterior placenta and the accompanying large number of blood cells in the amniotic fluid were associated with a marginally increased amniotic fluid AFP value but only placental RA cells. ${ }^{13}$

NORMAL AMNIOTIC FLUID AFP VALUE AND ABNORMAL (FETAL DISTRESS) CELLS

In 25 cases in which the amniotic fluid AFP value was normal and no major fetal abnormality was detectable on ultrasonic scanning abnormal RA cell types were seen. In 22 cases these were new RA cell types, termed fetal distress cells types I and II (table I). Three of these pregnancies ended in spontaneous abortion two to seven weeks after amniocentesis. A further two pregnancies resulted in a stillborn infant weighing $910 \mathrm{~g}$ and an infant weighing $2090 \mathrm{~g}$ who died of hyaline membrane disease in the neonatal period. Severe maternal toxaemia or pre-eclampsia occurred in three cases. In one of these pre-eclampsia was so severe that caesarean section was performed at 34 weeks' gestation, while the second mother was delivered at 36 weeks and the third at 38 weeks. Six infants were delivered before 37 weeks with birth weights of $2500 \mathrm{~g}$ or less, and eight babies were small for dates, weighing under $2500 \mathrm{~g}$ after 37 weeks.

Of the remaining three pregnancies with abnormal cells, one ended spontaneously at 22 weeks (two weeks after amniocentesis) but the amniotic fluid cells had a viability of less than $10 \%$. In the absence of maternal blood cells (which sometimes form clots binding viable amniotic fluid cells) and at gestations of under 26 weeks this low cellular viability indicates advanced fetal distress or even impending fetal death. ${ }^{16}$ In one case cellular viability was exceptionally low (5\% of the total cells) but there was also a dramatic reduction in total cell of numbers for the gestation of 19 weeks. This pregnancy ended in spontaneous abortion of a fetus with urogenital atresia at 26 weeks. Only one other case showed abnormal cells with a normal amniotic fluid AFP value. The infant had severe skeletal abnormalities (with no :recognisable syndrome) and died. The amniotic fluid cells were of a completely new and abnormal type.

\section{NORMAL AMNIOTIC FLUID AFP VALUE AND NORMAL RA CELLS}

In the remaining 133 pregnancies the amniotic fluid AFP concentrations were less than four standard deviations above the mean. Seven were twin pregnancies that had escaped detection by ultrasound. Five $\overrightarrow{0}$ of these resulted in the delivery of both infants with birth weights $\rightarrow$ below $2500 \mathrm{~g}$. In all cases of dizygotic twins, however, only one sample $\vec{\omega}$ of fluid was obtained at amniocentesis (presumably from only one of the sacs), and these cases are therefore excluded from further consideration.

One pregnancy resulted in the delivery of an infant weighing only o $1000 \mathrm{~g}$ and who died in the neonatal period. The mother had an $\vec{A}$ intrauterine contraceptive device in situ and had a severe pulmonary embolism at 27 weeks' gestation. The premature delivery was most probably due to maternal factors; interestingly no fetal distress cells were obtained by amniocentesis, which was performed at 17 weeks. One infant was stillborn at term: birth weight was $3600 \mathrm{~g}$, and there were no major abnormalities. A third infant in this group, in which $\infty$ there were no fetal distress cells, had first-arch syndrome, but the $\bigcirc$ abnormalities were not severe and he progressed normally.

\section{Discussion}

One of the problems encountered in screening maternal serum AFP concentrations during the second trimester is the non-specific nature of raised values. We have already shown ${ }^{12-1 ;} \bar{\partial}$ that examination of RA-cell morphology in amniotic fluid aids the differential diagnosis of fetal malformations associated with $\varnothing$ raised amniotic fluid AFP concentrations. Further details of $\overrightarrow{\vec{F}}$ such cases are given in table I. Now, however, we have identified $\stackrel{\circ}{3}$ two new types of RA cell (tentatively named fetal distress cells), $\vec{\partial}$ which appear to have value in the early prediction of spontaneous abortion and low birth weight.

The origins of these cells are unknown, although three major possibilities exist. The first is that they are derived from fetal lungs and released into the amniotic fluid as a result of fetal 3 stress (one spontaneously aborted fetus had large pleural effusions). Secondly, they may be derived from the fetal kidney

TABLE I-RA-cell morphology in 201 samples of amniotic fluid obtained by amniocentesis, and complications and outcome of pregnancy

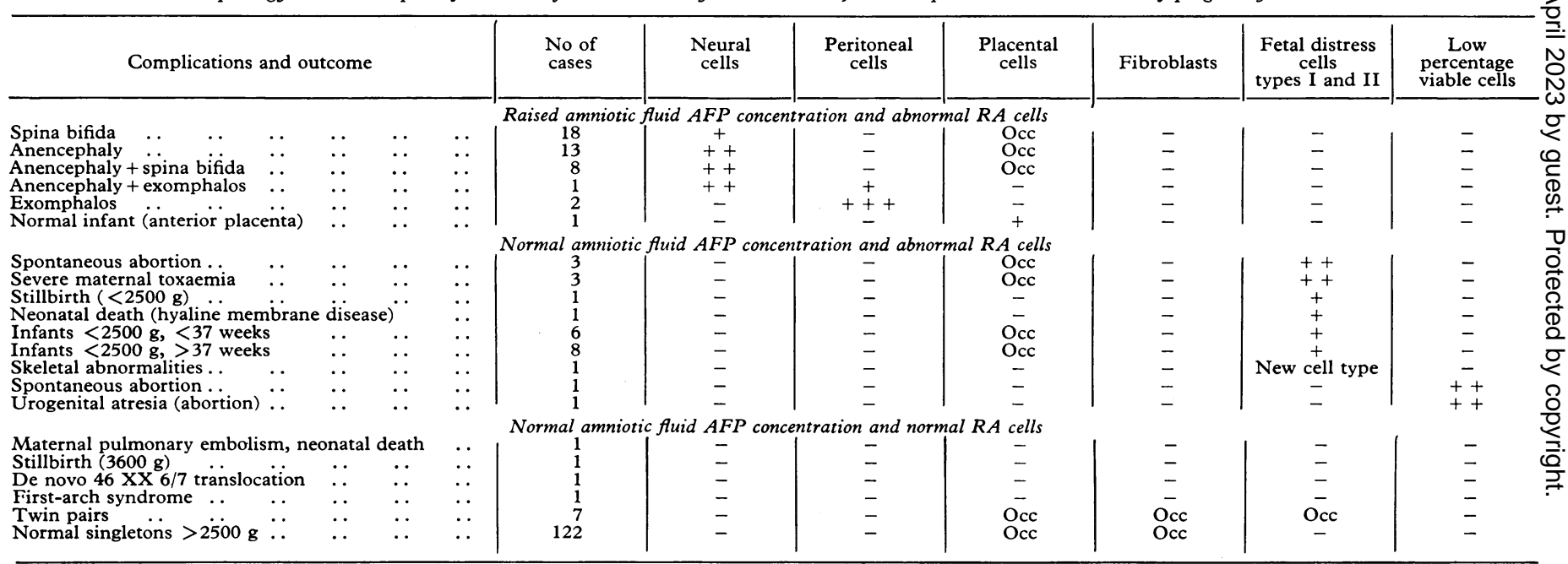

$+=$ Present. $\quad-\quad=$ Absent. $\quad$ Occ $=$ Occasionally present. 
as a result of, say, sudden hormonal stress and released into the amniotic fluid via the fetal urine. The third possible origin is from the placenta, though not in the same way as cells seen after transplacental amniocentesis, but rather by migration through pores in the membranes as a response to a developing unfavourable intrauterine environment. Quite probably the two cell types are derived from different sources. Interestingly, examination of the placentas of these infants showed that many were gritty or calcified and some had infarcts.

Some of the importance of fetal distress cells lies in their association with spontaneous abortions. In all five pregnancies in this series that aborted spontaneously before 28 weeks fetal distress cells or low proportions of viable cells were observed in the amniotic fluid and the consultant obstetrician informed. Abortions that occur after amniocentesis are often attributed to the amniocentesis itself. But if fetal distress cells are seen in the amniotic fluid it indicates that the pregnancy is already in difficulty and may go some way towards exonerating the amniocentesis if abortion occurs. Our observations will thus be useful in establishing the true amniocentesis-linked fetal wastage rates.

A second point of value of fetal distress cells follows from their ability to predict low birth weight. The reported association ${ }^{9-11}$ between a raised maternal serum AFP concentration in the second trimester and the delivery of a low birth-weight baby is comparatively weak. About $10 \%$ of such pregnancies result in preterm or small-for-dates infants, a figure too low to be useful in contemplating active management. If amniotic fluid is carefully examined for fetal distress cells, however, the predictive power is greatly sharpened. As shown in table II, of the 25 pregnancies with fetal distress cells or low proportions of viable cells, five resulted in spontaneous abortions and 20 in infants with birth weights below $2500 \mathrm{~g}$, while only one out of 12 pregnancies without such cells resulted in a low birth-weight infant. Furthermore, three of the mothers with small infants who were perfectly

TABLE II-Distribution of birth weights according to presence or absence of fetal distress cells. Twins and terminations of pregnancy excluded. ( $S A=S$ pontaneous abortion)

\begin{tabular}{|c|c|c|c|}
\hline Birth weight $(\mathrm{g})$ : & $>2500$ & $<2500$ & $S A<2500$ \\
\hline $\begin{array}{l}\text { No with distress cells } \\
\text { No without distress cells } \quad \ldots\end{array}$ & $\begin{array}{r}0 \\
124\end{array}$ & $\begin{array}{r}20 \\
1\end{array}$ & $\begin{array}{l}5 \\
0\end{array}$ \\
\hline
\end{tabular}

healthy at amniocentesis subsequently developed severe preeclampsia. If the methods reported here are extended to all amniotic fluid samples they will provide a basis for devising programmes for the active management of pregnancies at high risk of having a preterm or small-for-dates outcome.

We thank Dr G R Brown, Dr F R Clark, Dr I M Duthie, Dr A Herriot, Dr M Hill, Dr W A Liston, Dr J D O Loudon, Dr W G Paterson, Dr W Reid, and Dr J B Scrimgeour for their co-operation. We are also grateful to Dr K Buckton, Miss L Barron, Miss C Bowden, Mrs H Boland, Miss S Brown, Mrs P Eason, Miss A Fotheringham, and Miss $M$ Watt for their help. We particularly thank Dr J R Gosden for his help, encouragement, and advice. We are indebted to Professor $\mathrm{H} \mathrm{J}$. Evans for help and encouragement during the course of this work. The work was supported in part by a grant from the MRC to DJHB.

\section{References}

${ }^{1}$ UK Collaborative Study on Alpha-fetoprotein in Relation to Neural-tube Defects, Lancet, 1977, 1, 1323.

2 Kjessler, B, et al, Acta Obstetricia et Gynecologica Scandinavica, 1977, suppl No 69, p 20.

${ }^{3}$ Brock, D J H, et al, British fournal of Obstetrics and Gynaecology, 1978, 85, 575.

4 Seppala, M, et al, Lancet, 1976, 1, 303.

5 Kjessler, B, et al, Lancet, 1975, 1, 432.

6 Seppala, M, Clinical Obstetrics and Gynecology, 1977, 20, 737.

7 Seppala, M, and Ruoslahti, E, British Medical fournal, 1972, 4, 769.

${ }^{8}$ Seppala, M, and Ruoslahti, E, American fournal of Obstetrics and Gynecology, 1973, 115, 48.

O Brock, D J H, et al, Lancet, 1977, 2, 267.

10 Wald, N, et al, Lancet, 1977, 2, 268.

11 Macri, J N, et al, Lancet, 1978, 1, 660.

12 Gosden, C M, and Brock, D J H, Lancet, 1977, 1, 919.

${ }^{13}$ Brock, D J H, and Gosden, C M, British Medical fournal, 1977, 2, 934.

${ }_{14}$ Gosden, C M, Brock, D J H, and Eason, P, Clinical Genetics, 1977, 12, 193.

15 Brock, D J H, and Gosden, C M, Lancet, 1977, 2, 1168.

16 Gosden, C M, and Brock, D J H, fournal of Medical Genetics, 1978, 15, 262.

17 Gosden, C M, et al, in Proceedings of Third European Conference on Prenatal Diagnosis, Munich. In press.

18 Brock, D J H, et al, Clinica Chimica Acta, 1978, 82, 101.

19 Brock, D J H, Scrimgeour, J B, and Nelson, M M, Clinical Genetics, $1975,7,163$.

20 Gosden, J R, et al, Human Genetics, 1978, 41, 131.

21 Gosden, C M, et al, fournal of Medical Genetics, 1976, 13, 371.

(Accepted 29 August 1978)
ONE HUNDRED YEARS AGO The charges which have been made against private asylums are not likely, we think, to cease until some wholesome changes are made in the system under which they are carried on. For instance, Dr Lyttleton Forbes Winslow feels aggrieved, very naturally, that he should have been subject to charges of having, from interested motives, declared a person to be insane, who is, nevertheless, subsequently still allowed to be at large. On the other hand, so far as the statements made by that person are untrue, there is obvious ground for an action for libel; so far as they may be in any degree true and still offensive, it is obvious that a system is open to amendment, when the true description of what is done becomes a grievance. In this case; $\mathrm{Dr}$ Winslow does not deny that he saw the person, together with another physician, and that he declared her to be suitable for confinement; but it is alleged by the recalcitrant lady, who has successfully resisted incarceration, that the opinions and "independent certificates" were given by persons connected with him in business or by blood-ties. Now, if the law really allow an asylum-keeper to send any of his partners or dependents to give independent opinions on the subject of the necessity of sending patients to his asylum, or to sign the certificates, which are to become a source of large profit to him, that is obviously open to abuse, even if it be never abused. Our contention is not that private asylums are "hells," or are conducted with mala fides. There are many asylumkeepers, medical men, whom to know is to esteem; but our objection is to a system, which regularly combines the functions of boarding- house keeper, on a highly calculated scale of remuneration, with the functions of a governor of a house of detention; and which does not place the houses under such frequent and regular observation as to insure that no "unconscious bias" shall detain the patient in prison, after it is as good for him to be at liberty, even though it be no better for him or her, and worse for the asylum-keeper. Of course, a palpable distinction exists between that large class of persons who, although "not of sound mind," are not yet necessarily the better, and often the worse, for being shut up in an asylum, and those who require such treatment; yet there is reason to fear that distinction is not always present to the minds of those who are asked to sign certificates of unsoundness of mind, or of those who, by such certificates, obtain control over the unsound in mind. It should, however, always be borne in mind that, once certified, a lunatic is very much in the power of the holder of the certificates; and that some asylum-keepers appear to entertain the opinion that every one who is of unsound mind should be placed in custody at their establishments. It will not always be found that the medical proprietor of an asylum lives at his asylum, while many places of the kind belong to people of no professional knowledge, standing, or sympathies, who merely treat the patients as means of income. Of course, there are "resident" medical officers at such places, and that is enough to avert all suspicion of mala fides; but it is easy to see that this is a better arrangement for a prison than for a house of cure, and all private asylums should, in our opinion, be simply the latter. (British Medical fournal, 1878.) 